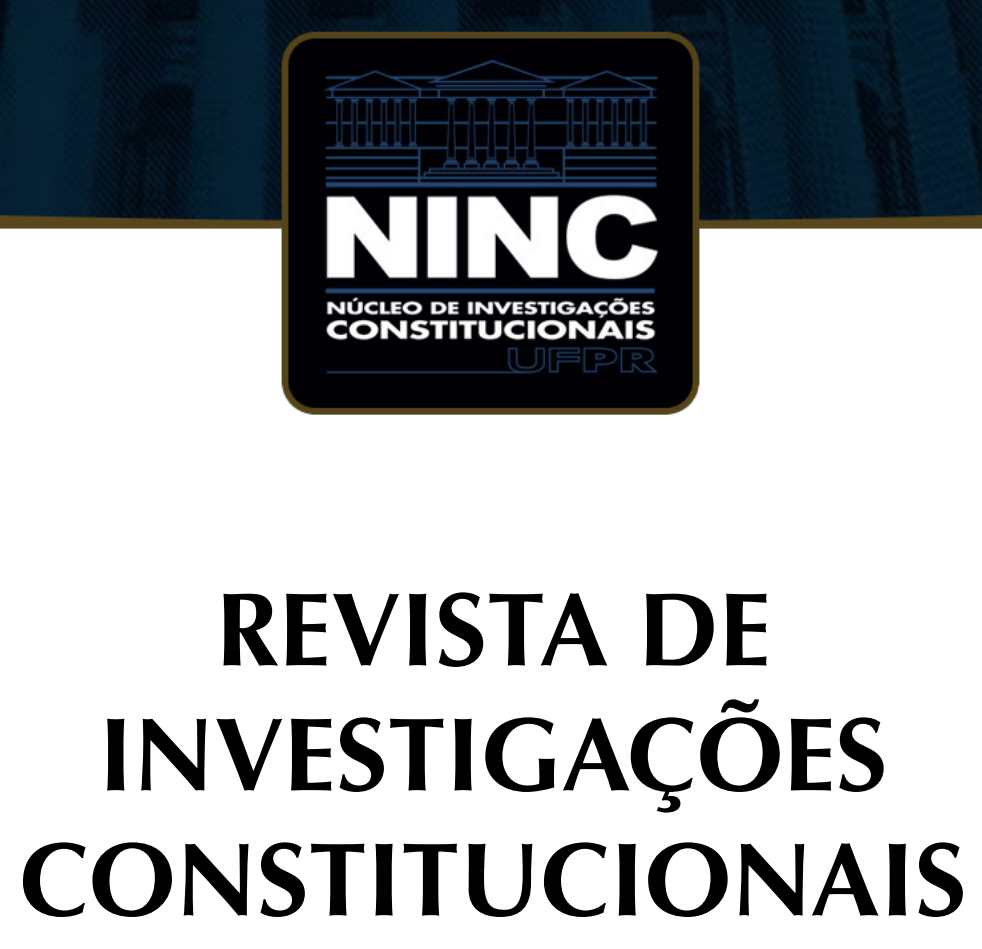

vol. 4 | n. 1 | janeiro/abril 2017 | ISSN 2359-5639 | Periodicidade quadrimestral Curitiba | Núcleo de Investigações Constitucionais da UFPR | www.ninc.com.br 


\section{The prohibition of wearing veil in public schools in Egypt: an analysis of the Egyptian Supreme Constitutional Court jurisprudence}

\section{A proibição da utilização de véus em escolas públicas no Egito: uma análise da jurisprudência da Suprema Corte Constitucional egípcia}

MOHAMED A. 'ARAFA*

Indiana University School of Law (United States of America) Alexandria University Faculty of Law (Egypt) marafa@iupui.edu

Recebido/Received: 26.01.2017/ January 26th, 2017 Aprovado/Approved: 06.02.2017 / February 6th, 2017

\section{Abstract}

On 18 May 1996, the Supreme Constitutional Court of Egypt upheld Case No. 8, which discussed the constitutionality of an administrative act of the Ministry of Education which, regulating the uniforms that should be used in Egyptian public schools, prohibited the use of a veil. The article exposes the factual content that involved the case, analyzing this decision through the fundamenta right to religious freedom and the necessary limits that must be imposed in a liberal interpretation of Islamic Law.

Keywords: Islamic Law; veil; public school; religious freedom; Egypt

\section{Resumo}

Em 18 de Maio de 1996, a Suprema Corte Constitucional do Egito julgou o caso $n^{\circ} 8$, no qual se discutia a constitucionalidade de um ato administrativo do Ministério da Educação que, ao regular os uniformes que deveriam ser utilizados nas escolas públicas egípcias, proibiu a utilização de véu. $O$ artigo expõe o conteúdo fático que envolveu o caso, analisando essa decisão através do direito fundamental à liberdade religiosa e os limites necessários que devem ser impostos a uma interpretação liberal da Lei Islâmica.

Palavras-chave: Lei Islâmica; véu; escola pública; liberdade religiosa; Egito.

\section{CONTENTS}

1. Introduction; 2. The Parties and the Main Facts of Case 8/1996; 3. The SCC's Holding; 4. The Impact and Influence of Case 8/1996 (Assessment); 5. References.

Como citar esse artigo/How to cite this article: 'ARAFA, Mohamed A. The prohibition of wearing veil in public schools in Egypt: an analysis of the Egyptian Supreme Constitutional Court jurisprudence. Revista de Investigações Constitucionais, Curitiba, vol. 4, n. 1, p. 69-85, jan./abr. 2017. DOI: 10.5380/rinc.v4i1.50341.

* Adjunct Professor of Islamic Law at Indiana University Robert H. McKinney School of Law (Indianapolis, United States of America). Doctor of Juridical Science (S.J.D.), 2013, Indiana University Robert H. McKinney School of Law (Indianopolis, USA). Assistant Professor of Criminal Law and Criminal Justice at Alexandria University Faculty of Law (Egypt). Master of Laws (LL.M.) in American Criminal Law and Criminal Justice, 2008, University of Connecticut School of Law (USA). Bachelor of Laws (LL.B.) 2006, Alexandria University, Faculty of Law (“English" Department) (Alexandria, Egypt). E-mail: marafa@iupui.edu. 


\section{INTRODUCTION}

Case No.8 of 1996 is a landmark decision of the Egyptian Supreme Constitutional Court ("SCC") and represents one of the most significant judicial rulings of a structural remedy for the interpretation of Article 2 of Egypt 2014 Constitution. The jurisprudence of the SCC is essential to advance a moderate (liberal), rights-protecting interpretation of Sharie'a. In this case, the SCC held that a rule on face-veiling in public schools is compatible not only with Islamic law, but with certain human rights guaranteed by the Constitution:, as freedom of expression and freedom of religion. This decision dealt with the SCC's view on Islamic ijtihad (legal reasoning), and, gives insight into the Court's views on civil and political rights context. Further, this case offers fascinating prospects for comparative constitutional law experts, and international human rights activists, as laws restricting women's rights, (particularly to cover/veil) have been confronted as unconstitutional in several Arab and European countries (Headscarves in the headlines 2004). Indeed, the SCC judgment facilitated fruitful comparative analysis and debate on the free exercise of religion, freedom of expression, children and women's rights. This case has been featured as a cornerstone in Middle Eastern constitutional theories, as it examined Egypt's constitutional jurisprudence-which has the power to review the constitutionality of laws and decrees, interpretation of Islamic law. It has developed its private adequate "interpretation from within" of spiritual norms-facing a liberal-religious split, as Egypt have observed a substantial growth in the phenomena of extreme Islamism, under Presidents Gamal 'Abdelnasser, Anwar Sādāt, and recently under the exiled President Mohammad Morsi ousted by the popular protests on June 30, and the military on July 3, 2013.1

This brief article first covers (in Part II) the background of the case and its facts, before turning in (Part III) to the holding itself and its most noticeable feature-the Court's declaration of a liberal interpretation of the Sharie' $a$ law. Part IV provides a detailed assessment of that ruling, addressing the impact of the case both within and outside of Egypt, as constitutional courts in Mediterranean countries, as in Egypt, have situated themselves as central secularizing powers in their societies. Also, it proposes that the ever-accelerating confidence on domestic supreme judicial bodies in religious constitutionalism concerning religion and state enquiries offers significant understandings for accepting the political roots of judicial authority and the circumstances under which political aspect to the judiciary is probably to ensue.

1 'ARAFA, Mohamed. Whither Egypt? Against Religious Fascism and Legal Authoritarianism: Pure Revolution, Popular Coup, or a Military Coup d'état? Indiana International and Comparative Law Review, Indianopolis, vol. 24, n. 4, p. 859-897, 2014. p. 865-871. 


\section{THE PARTIES AND THE MAIN FACTS OF CASE 8/1996}

On May 18, 1996, the SCC under the Presidency (Chief Justice) of Counselor Dr. 'Awad el-Murr, and [with] the membership of other seven chief justices, including the Commissioners Body's President and the secretary general, referred to the Court from the Administrative Court by decision issued in Case No. 21 of judicial year 49 undertaken by Mahmoud Sami Wasil, in his capacity [as a guardian] of his two daughters, Mariam and Hajir against the Education Minister, the director of the Alexandria's Education Board, and the Isis's Manger Girls High School in al-Siyuf. Regarding the procedures, the Alexandria Administrative Court ruled that the file should be referred to the SCC to check the constitutionality of the Ministerial Decision No. 113 of 1994 [as expounded by Decision No.208/1994]. Then, the State Litigation Authority-the body that is charge of representing the state in litigation-submitted a memorandum defending the governmental [decree] and requesting case's denial. The Commissioners Apparatus then prepared a report with its opinion. ${ }^{2}$ It should be noted that Egyptian administrative courts have crucial jurisdiction over cases in which the state [government] is a party and this case focuses on the actions of the school's Manger, who is performing in accordance with an official administrative decree issued by the Education Minister. Yet, administrative courts are not allowed to interpret the Constitution, so when challenged with a case that requires a constitutional' interpretation, it must refer it [on renvoi] to the SCC, which is permitted, on its competence, to decide non-constitutional matters and to issue a final ruling in the case. ${ }^{3}$

Briefly in this case, two daughters, filed Case No. 21(49) at Alexandria Administrative Court against the Education Minister in which their [father] required a presiding awkward application of and stopping the negative judgment that had been issued excluding entry of his daughters into their school. The daughters have been expelled from the school-when he had gone with them to the Isis school and was surprised-due to the enactment of a decision by the Education's Minister proscribing female students wearing the niqab (veil) from entering, a decree in which the father proclaims that represents a direct transgression of Articles 2 and 53 among others of the Constitution, regarding the Islamic law's understanding and equality in public rights and duties. ${ }^{4}$ The father claimed that Article 2 reads that "Islam is the religion of the State and Arabic is its official language. The principles of Islamic Sharie'a are the principle source of legislation"

2 ELMORR Awad et al. The Supreme Constitutional Court and Its Role in the Egyptian Judicial System. In: BOYLE, Kevin; SHERIF, Adel (Eds.). Human Rights and Democracy - The Role of the Supreme Constitutional Court of Egypt. Hague: Kluwer Law International, 1996. p. 37-53.

3 SHERIF, Adel. Constitutional Law. In: MAUGIRON Nathalie; DUPRET Baudouin (Eds.). Egypt and its Laws. London: Kluwer law international, 2002. p. 325-330.

4 ELMORR, Awad. The Supreme Constitutional Court of Egypt and the Protection of Human and Political Rights. In: MALLAT, Chibli (Ed.). Islam and Public Law. [s.I.]: Springer Netherlands, 1992. p. 229-258. 
and Article 53-confirms the conservation of personal freedom [and bans] any violation to it-as it stipulates that "Citizens are equal before the law, possess equal rights and public duties, and may not be discriminated against on the basis of religion, belief, sex, origin, race, color, language, disability, social class, political or geographical affiliation, or for any other reason. Discrimination ... are crimes punishable by the law. The State shall take all necessary measures to eliminate all forms of discrimination ..."

During its examination of the case and the motion to suspend execution of the defendant's ministerial decree, the SCC recited that the Administrative Court based its decision on the fact that the [high school's] decision to dismiss the girls was based on Decree 113/1994 [issued on August 17, 1994 by Educational Minister] which detailed the school uniform in its form, color, and configuration, and clarified by ministerial decree No. 208/1994. The SCC recited that "is within the exclusive competence of the SCC to decide whether these two decisions violate freedom of religion protected in the Constitution ...." Legally speaking, the Egyptian legal system creates a hierarchy of legislative enactments as follows: (a) constitution; (b) statute; (c) regulation (bylaw), and (d) decree/decision. In this case, the "decree" being confronted and thus, is a formal administrative act. 5

\section{THE SCC'S HOLDING}

The SCC decided against the defendant, concluding that the contested Decision does not contradict the Constitutional provisions in any way. Further, it stated that the dad raised remedies only under constitutional provisions 2 and 53 . Through its ex-officio jurisdiction, the SCC, though, has found that Article 64 concerns are tacitly involved in the case, which reads "Freedom of belief is absolute. The freedom of practicing religious rituals and establishing places of worship for the followers of revealed religions is a right organized by law." The Court defined the freedom created in this provision as "freedom of "aqida (creed) rather than freedom of din (religion)".6 Also, it said that "it is obvious from the provisions of Decree113/1994 that male and female students in public and private schools are required to wear a single uniform with the following features:

a. First, Primary Phase, Boys/Girls: A linen apron in the color selected by the educational board, it is allowed to wear pants in winter ... [if it is] appropriate according to what the educational directorate has decided. Girls can substitute for the apron a blouse and skirt of appropriate length and for boys ...

\footnotetext{
5 RUGH, Andrea. Reveal and Conceal: Dress in Contemporary Egypt. Syracuse: Syracuse University Publications in Continuing Education, 1987.

6 BROWN, Nathan; LOMBARDI, Clark. The Supreme Constitutional Court of Egypt on Islamic Law, Veiling and Civil Rights: An Annotated Translation of Supreme Constitutional Court of Egypt Case No. 8 of Judicial Year 17 (May 18, 1996). American University International Law Review, Washington, vol. 21, n. 3, p. 437-460, june 2006. p. 444-445.
} 
b. Second, Elementary Phase:

1. Boy Students: Long pants-shirt in appropriate color, in the winter a sweater . .. may be worn in accordance ... directorate decides.

2. Girl Pupils: White blouse-linen apron with suspenders in the color chosen by the educational Board ... The apron may be replaced with a long blouse of appropriate length ... Upon written request from the guardian, the student may wear a hair cover in a color selected by the educational Board, if does not obscure the face.

a. Third, High School Period:

1. Male Students: Long pants-shirt in an appropriate color . . . to educational board decides.

2. Female Students: White blouse-skirt of appropriate length ... upon written request from the guardian, the student may wear a hair cover in a color selected ..., if does not obscure the face."

Also, the decree states that school uniforms for both male and female students in every school will be posted in a visible place at least two months prior to the beginning of the school and students who violate the decision may not enter their school or be affiliated with it. In order to avoid any sort of ambiguity in this decree, the Minister of Education enacted a second decree clarifying the former one and identifying its content, which reads:

First, regarding female students within elementary and high schools:

a. "Upon written request from the guardian" means that the guardian [dad] must be cognizant of the student's will (choice) to wear hair veil, and that the choice comes from her own free will without pressure/coercion from an individual other than the custodian. The student shall not be prohibited from entering her school if she wears a hair scarf and her entry shall take place awaiting upon examination of the guardian's awareness.

b. "Hair Cover" means that the cover that the student selects according to her own free will may not cover the face. No examples ... for hair covering shall be contravene this.

Second, regarding all students in the whole educational phases: The uniform shall be proper in appearance and the style in which it is worn, conserving the uniform within the society's morals, traditions [teachings]. Each uniform that invades these rules considers a violation of the school uniform; and it is not allowed for the girl student wearing one to get in her school.7 This holding has been documented to understand,

\footnotetext{
7 BROWN, Nathan; LOMBARDI, Clark. The Supreme Constitutional Court of Egypt on Islamic Law, Veiling and Civil Rights: An Annotated Translation of Supreme Constitutional Court of Egypt Case No. 8 of Judicial Year 17 (May 18, 1996). American University International Law Review, Washington, vol. 21, n. 3, p. 437-460, june 2006. p. 446.
} 
the method in which the SCC applies its recent perspective to improve a secular, rights-protecting elucidation of Sharie' $a$, that secured under the Constitution.

Accordingly, the SCC has been reliable in interpreting what the Constitution instructs in its second article since its amendment in 1980-confirming that the principles of Islamic Sharie' $a$ are [the] chief source of legislation. The Court has said that the principles of the Islamic Sharie' $a$ bind both the legislative and executive authorities. Among those, are the provisions of the challenged Decree113/1994 [explicated by Decree 208/1994] that it is not permitted for any statutory text to contradict the Sharie'a rulings: al-ahkam al-shar'iyya alqat'iyya fi elthubut wa aldalalah (these rulings only not subject to ijtihad (analogy), as they indicate the mabadi'a kulliyya (universal principles) and its usuliha al-thabita (fixed roots), which admit neither interpretation nor replacement that are unequivocally certain regarding their authenticity and meaning, hence, ijtihad is forbidden, so it is unconceivable that the explanation of [such values] would amended with a change of time and place, as it is haram (forbidden) to breach them or rotate their meaning. Over time, Egypt's SCC outlined an approach to such cases, based on the modernist Islamic thought, led by a diverse religious scholars, that focused on the query of how to cognize (interpret) the Sharie' $a$ in an appropriate manner for a modern society's needs.

The Court pointed out "that the use of reasoning, where there is no [scriptural] text, develops qawa'id'amliyya (practical guidelines) that are, in their implications, softer for the folks and more concerned with their daily affairs and [that] better defend their masalihhim al-haqiqiyya (true interests). ${ }^{8}$ Thus, statutory texts seek to recognize factual welfares in a suitable way for the individuals, confirming that the essence of God's law [Sharie'a] is justice, and that closing it (i.e. prohibiting re-interpretation) is neither adequate nor necessary, as the Prophet's companions who used ijtihad, often created decisions totally motivated by the public interests keeping them from darar (harm), and saving them from pain, bearing in mind that these benefits grow in light of the circumstances of the society's needs." Legally speaking, the legislator bound by the constitutional parameters and cannot exceed, contravene, or decline them. ${ }^{9}$ Then the Court recited "this is the Islamic [Sharie'a] in its usuliha wa manabitiha (roots and sources), developing by necessity, declining [stringency]. In situations where there is no [obvious] text, ijtihad is only constrained by its dawabituha alkulliyya (universal controls)

\footnotetext{
8 BROWN, Nathan; LOMBARDI, Clark. The Supreme Constitutional Court of Egypt on Islamic Law, Veiling and Civil Rights: An Annotated Translation of Supreme Constitutional Court of Egypt Case No. 8 of Judicial Year 17 (May 18, 1996). American University International Law Review, Washington, vol. 21, n. 3, p. 437-460, june 2006.

9 BROWN, Nathan; LOMBARDI, Clark. The Supreme Constitutional Court of Egypt on Islamic Law, Veiling and Civil Rights: An Annotated Translation of Supreme Constitutional Court of Egypt Case No. 8 of Judicial Year 17 (May 18, 1996). American University International Law Review, Washington, vol. 21, n. 3, p. 437-460, june 2006.
} 
and Islamic law goals are not congested, it is not permitted to require the wali al'amr (follow mere) opinions in issues of the practical Islamic al-ahkam al-fara'iyya (legal rulings) that subject to development per se." Also, the orthodox Islamic scholars' views on subjects related to Sharie' $a$ are not granted any inviolability [sanctity] or placed beyond assessment or verification, as they can be switched by other [Islamic interpretations]. In the same vein, opinions based on ijtihad in contested queries do not have any binding force per se applying to those who do not claimed them, as it is not acceptable to hold [such opinions] to be stable, established that Islamic law cannot be infringed.

The Court defined in its ruling ijtihad and its functions, as it "must track methods of reasoning out the alahkam (rulings) and al-qawa'id al-dabita (mandatory chains) for the Sharie' $a$ furu'(branches), preserving the main maqasid (objectives)".10 Thus, the SCC has approved its influential authorization devotedly and has responded with a robust disposition to use its validity and recently enlarged policymaking ability to improve a reasonable liberal interpretation of Sharie'a norms, as in most cases, «ijtihad» is required. ${ }^{11}$ Accordingly, the SCC has shifted from the prehistoric traditions of fiqh (Islamic jurisprudence) or the collective facts and studying the schools of jurisprudential thought and has established a new framework for deducing and understanding Islamic law as the fallible human effort to apprehend the content of that guidance. Then the Court elaborated: ". . . there is no duty to legislate following the classical fiqh contents, as the new legislation must not be in contrast with the bulk of the law, but only after enactment and must achieve the "common good»" (Ibid.). It should be noted that the legal interpretation of SCC must be outlined considering the religion's role "at large" in the society, as a cultural factor, even in a strictly legal perspective, and hence, the SCC role is not to establish the religion in the legal system, rather is a symbolic reference of the religion's importance in the Egyptian society. So, the point is not so much whether the SCC is mentioned in the Constitution or not, but rather its legal tie must be accommodated with the liberal commitment to democratize the society. ${ }^{12}$

Further, the SCC highlighted that "it is responsible for the obligation to watch out for any transgression of these Islamic rulings that are absolutely certain and to transpose any [legislative] qai'da (rule) that contradicts them. This provision located the Sharie' $a$ rulings in a superior place over these [statutory] rules...13 One should bear in mind that these [judgments] are [the Sharie'a] general structure and initial columns,

\footnotetext{
10 LOMBARDI, Clark. State Law as Islamic Law in Modern Egypt. Leida: Brill Academic Publishers, 2006.

11 BROWN, Nathan. The Rule of Law in the Ancient World: Courts in Egypt and the Gulf. Cambridge: Cambridge University Press, 1997.

12 Rector of the Azhar Univ. v. President of the Republic, Case No. 20 of Judicial Year No. 1 (Sup. Const. Ct. 1985), translated in 1 Arab L.Q. 100, 104 (Saba Habachy trans., 1986)

13 BROWN, Nathan. Islamic Constitutionalism in Theory and Practice. In: COTRAN, Eugene; SHERIF, Adel. (Eds.). Democracy, the Rule of Law and Islam. Hague: Kluwer Law International, 1999.
} 
whose stresses enforce themselves enduringly and avert creation of any legal rule that interrupts them. ${ }^{14}$ Also, it stated that "this is not to be considered detrimental/negation of what is known by 'alim min al-din bi al-darura (necessity of religion); al-ahkam al-zanniyya (presumptive rulings) are not categorically definite on their authenticity, meaning, or both") ${ }^{15}$. They fall under ijtihad which is limited and beyond which does not cover. They improve by their nature-changing according to time period and place, in order to assure their flexibility and vitality, and to confront different events per se. ${ }^{16}$ Also, it touched on legislator's authority [limits] within huquq (rights') regulation, as disregarding or curtailing constitutional public rights outbreaks fields of vivacity and likewise it is prohibited to regulate these rights in a manner that contradicts their meaning; as its regulation must be unbiased and reasonable.

The Court said "It is obvious that the arguments ... regarding the challenged Decree, along with those made by the plaintiff [students' Dad] ... deal basically with the female' requested uniforms (features and wearing way...) and the covering manner. The questioned instructed that each girl within the educational phases have a prescribed uniform style that protects her general features (proper for her and that does not disclose what must be covered), and wearing style must safeguard her modesty within the society's ethical traditions." The Court described the Islamic law stance on shaping the individual personality and said "jawhar al-ahkam (ruling's essence) is the most significant for defending the creed ... On belief's, women activities must be most pure of heart and most summoned to piety, as Islam raised the woman's share and inspired her to maintain her 'afetiha (chastity), ordered her to defend herself from degradation, so she would locate herself above things that could dishonor her, particularly via her dress, sensitivity in speech, walking's tweak, ... [The woman] does not have the right to spontaneously select her dress as she wants, select it according to her fancy, or claim that her costume is only her personal demand... However, her cloth style is not fixed by nusus maqtu' biha fi thubutiha aw dalalatiha (theological scripts that have been dogged to be definite on its authenticity/meaning). Consequently, women's attire is a debatable issue in which ijtihad never ends, as they remain open within a secure, general framework defined by the Qur'anic provisions (Qur'an 24:31 \& 33:59) and it cannot be concluded that a woman's cloth cannot be altered as long as they do not contradict an absolutely certain text, and acceptable recurring 'urf (prevailing customs).

14 LOMBARDI, Clark. Designing Islamic Constitutions: Past Trends and Options for a Democratic Future. International Journal of Constitutional Law, Washington, vol. 11, n. 3, p. 615-645, sept. 2013.

15 Awad-Allah v. Abd-El-Al, Decision 28, Judicial Year 1 (May 4, 1985).

16 'ARAFA, Mohamed. Whither Egypt? Against Religious Fascism and Legal Authoritarianism: Pure Revolution, Popular Coup, or a Military Coup d'état? Indiana International and Comparative Law Review, Indianopolis, vol. 24, n. 4, p. 859-897, 2014. p. 888-889. 
Additionally, the Court recited that classical scholars disagreed among themselves regarding the interpretation of Qur'anic provisions and of what has been conveyed from the Prophet within the authentic and weak (non-authentic) hadiths and only agreed upon that Islamic law in its essence entails her cloth's regulation. ${ }^{17}$ They have been agreeing upon not placing women in uncomfortable circumstances (her whole body were considered 'awra [sexual private parts]), as she must perform tasks that will involve her mixing with others. 18 Muslim jurists in consensus of that her clothing shall fulfill two elements, necessity and customs/traditions' maintenance. Accordingly, it is not acceptable for her to surpass the moderation' boundaries and should not cover her entire body so as to restrict her. Under the theory of al-ahkam al-khamsa(h) (the Scale of Five Qualifications), on the proscription of a thing, it should not related to something ihtemali (probable), but to nass qat'i (unquestionable certain text) and if not, it will become conceivable based on the al-ibaha [al-asl fi il'ashi'a al-ibaha] (permissibility norm). And then, there is no dalil (indictor) in the Qur'anic texts or Sunnah legally conforming female's clothing, to be ratified by the Sharie' $a$, [so, must veil totally; [niqab or bourquo' included] ... is not an acceptable analysis, nor is it known by necessity of religion ... Therefore, a complete veiling of a woman is not known by necessity to be shar'i (legally certain), and covering her whole beauty is not confirmed by the law, but her appearance must protect her modest mentality, expedite her genuine input in which her [private] life affairs require, [must] defend her from humiliation, and keeping her out of ithm/fasad (sin). ${ }^{19}$

Thus, after careful provisional reviewing within the challenged decree designates that each student [may] wear a cover that does not hide the face and that she has selected based on her free will, provided that her guardian verifies that veiling her head is not a result of coercion (intervening in her affairs) but rises according to her aspiration, [a certification] which may be given after she starts her studies. Also, the decision specifies that [a schoolgirl's] uniform must be proper according to her personal values in a manner that preserve her modesty and consistent with the society's morals and customs. Based on the aforementioned reasons, the Court stipulated that the "challenged Decree does not contradict, the explicit text of Article 2 and in debatable matters, the wali al'amr (leader) has the authority (right) to develop his/her own ijtihad to assist the individuals' affairs and redirect what is accurate from the surrounding traditions, as long as they do not contradict the Sharie'a maqasid (universal spirit)." And the "ministerial

17 BROWN, Nathan; LOMBARDI, Clark. Do Constitutions Requiring Adherence to Shari'a Threaten Human Rights? How Egypt's Constitutional Court Reconciles Islamic Law with the Liberal Rule of Law. American University International Law Review, Washington, vol. 21, n. 3, p. 179-435, june 2006.

18 WEHR, Hans. A Dictionary of Modern Written Arabic [s.l.]: Milton Cowan ed., 1974.

19 BROWN, Nathan; LOMBARDI, Clark. Do Constitutions Requiring Adherence to Shari'a Threaten Human Rights? How Egypt's Constitutional Court Reconciles Islamic Law with the Liberal Rule of Law. American University International Law Review, Washington, vol. 21, n. 3, p. 179-435, june 2006. 
decree just obliges each female student in various educational phases to wear a suitable uniform, which shades her without revealing her and which covers her nakedness . .. and her style wearing must evade this and be appropriate to the religious standards, which attach her by necessity to the societal ethics and based on that decision, [a female student] may cover only her head and not hide her face or palms." On the freedom of religion, the court said that the concept of this freedom does not grant the fortification to someone practicing his/her belief in a way that may harms other faiths. Nor is the state to purport either secretly or publicly conversion to a faith under its protection, forcing others to embrace it and may not interfere by punishing those who practice a creed that it has not validated (agnostics), as mostly in Egypt they only acknowledge the three Abrahamic religions (Judaism, Christianity, and Islam). 20 The Court recited:

Nor may the freedom of belief be separated from the freedom to worship/practice its rites and this why the Constitution required when it connected these two liberties, by instructing that freedom of faith and freedom to practice spiritual deeds are guaranteed. The second represents the indicator of the first ... this makes it promising to say that the first freedom [...] is unlimited. The second freedom [...] may be restricted by ordering it sustaining some of the higher welfares associated with it, what links it with the conservancy of the public order and moral ideals and the resistance of the others' rights and their freedoms

The plaintiff claimed that the decree infringes personal freedom, arguing that this freedom's backbone is the self-independence of each individual in all matters based on life privacy (its conditions, model, characters, etc...). The Court said "In fact, this [argument] is rejected and thus the challenged decree doesn't invade the religious freedom, rescind its basics, or impede the spiritual practice or confront the din (religion's essence) in its al-usul al-kulliyya (common heritages) that the Islamic law created".21 "It articulates the acceptable application of ijtihad targeting only to adjust girls' dress in educational institutions. Although, education is a public right assured by the State and its supervision according to the constitution, State should never ever intervene in these very personal matters of the individual's private life (privacy right) based on unjustified grounds of watching over the whole educational process in all its mechanisms and to maintain the connections between education and society's necessities." Finally, the Court recited that the "State's regulation of male and female student's affairs in some

20 BROWN, Nathan; LOMBARDI, Clark. Do Constitutions Requiring Adherence to Shari'a Threaten Human Rights? How Egypt's Constitutional Court Reconciles Islamic Law with the Liberal Rule of Law. American University International Law Review, Washington, vol. 21, n. 3, p. 179-435, june 2006.

21 'ARAFA, Mohamed. Whither Egypt? Against Religious Fascism and Legal Authoritarianism: Pure Revolution, Popular Coup, or a Military Coup d'état? Indiana International and Comparative Law Review, Indianopolis, vol. 24, n. 4, p. 859-897, 2014. p. 887. 
organizations is acceptable through the logical correlation between its content and its purposes and this is fulfilled in this case in which the questioned Decree established school's uniform style within the various educational phases. This Decree did not release the male and female clothing from all limits, but it regulate it to reach modesty and suitability standards and to conserving their mental and physical health, and not disturbing their religious values and not isolating them."

\section{THE IMPACT AND INFLUENCE OF CASE 8/1996 (ASSESSMENT)}

This case, touched on several aspects of policy and decision-making, including harmonization with domestic authorities regarding the application of Islamic law or the interpretation of the Sharie' $a$ Clause Guarantee ("SCG"), as an eternity clause. Although the Court upheld the constitutionality of the governmental decree and ruled that the appropriate Sharie' $a$ commands were contestable, lithe, and subject to development, it also ruled that the relevant religious (divine) law was not sacred and could be modified, adjusted/replaced. The Court succeeded in vastly increasing the elaboration in which a woman wore clothes that were modest and didn't show any 'aura, she was enduring by the Sharie' $a$ spirit.22 The SCC's ruling on the niqab matter is remarkable. First, the SCC echoed its obligation on a potential implementation of Article 2 to laws endorsed after the 1980's historical amendment.23 Second, it extended the SCC's jurisdiction to ministerial decrees, so escalating the scope of legislation that falls under Article 2. Third, it underscored the requisite for developing a moderate interpretation of the same article that would be reliable with other constitutional provisions defending public rights. ${ }^{24} \mathrm{Fi}-$ nally, the Court involved in a self-sufficient functional interpretation of both the Qur'an and authentic Sunnah. All in all, the Court established its specific interpretation of ijtihad irrespective of the opposing attitudes in Islamic jurisprudence, and its classical techniques, and thus, it situated itself as a de facto interpreter of divine ideals and legal guard on the Sharie' $a$ values to avoid any extreme ideology or radical philosophy. It has advanced a flexible method to interpreting the divine law that differentiates between "unalterable and universally binding principles, and malleable application of those

22 LOMBARDI, Clark. Note, Islamic Law as a Source of Constitutional Law in Egypt: The Constitutionalization of the Shari'a in a Modern Arab State. Columbia Journal of Transnational Law, New York, vol. 37, 1998. p. 111-112.

23 LOMBARDI, Clark. Note, Islamic Law as a Source of Constitutional Law in Egypt: The Constitutionalization of the Shari'a in a Modern Arab State. Columbia Journal of Transnational Law, New York, vol. 37, 1998. p. 106-113.

24 LOMBARDI, Clark. Note, Islamic Law as a Source of Constitutional Law in Egypt: The Constitutionalization of the Shari'a in a Modern Arab State. Columbia Journal of Transnational Law, New York, vol. 37, 1998. p. 107-108. 
principles".25 Laws that breach a strict, irreversible principle are acknowledged unconstitutional and invalid (annulled), but in the meanwhile, ijtihad (contemplation) is allowable in cases of textual gaps, or where the relevant rules are ambiguous/open ended. Moreover, the government has been given comprehensive legislative will in policy areas where the Sharie' $a$ is found to provide uncertain or numerous responses, provided that the statutory product does not violate the Sharie' $a$ spirit (purposes) based upon a sensible, impartial secular ijtihad.

Based on that ruling, the individual reasoning rules via a mujtahid (qualified scholar) regulate the individuals' affairs to defending those interests that are legally appropriate. ${ }^{26}$ In Islam, a mujtahid is eligible if possess the (a) ultimate awareness of legislating ayaat al'ahkam (verses) along with the knowledge of Sunnah and its narrator's reliability; (b) understanding of nask'h (abrogating/abrogated provisions) rules based on the repel theory; (c) knowledge of ijm'a (consensus) and the familiarity with 'ilm usul al-figh (ijtihad's methodology through a complete understanding of reasoning); (d) mastering the Arabic language along with piety (Islam), and (e) thorough understanding of makasid al-sharie'a (Sharie'a objectives). Generally, the mujtahid's knowledge should be necessary in which it can be absolutely certain and then undisputable. This ruling is significant to determine the concept of the religious clause in a contemporary State constitutions and to track the possibility of a pluralistic interpretation the Sharie' $a$ reference consistent with the democratic state's governance. 27 The crises of Islamic law are due to the conflict with the modern state institutions. ${ }^{28}$ Likewise, the "eternity clause" in the country's constitution [basic law] is designed to guarantee that the legislation/constitution cannot be altered by amendment, as it recognizes that certain principles are part of the legal system, above and beyond the written constitution, and must be protected. 29

In this case, we have to acknowledge that: (a) the Sharie' $a$ is mentioned and explained in the constitution's preamble, a place in which the constitutional process is described in its complete "temporary references" [a typical element of constitutions, in which founding values are expressed by universal timeless formulas for society's regulation]; (b) both Congress and the SCC have limits to amend the Sharie' $a$ principles, and (c) SCC's former and recent decisions declared the presence of the Sharie' $a$ values in a

25 BROWN, Nathan. Islamic Constitutionalism in Theory and Practice. In: COTRAN, Eugene; SHERIF, Adel. (Eds.). Democracy, the Rule of Law and Islam. Hague: Kluwer Law International, 1999. p. 491-496.

26 HALLAQ, Wael. A History of Islamic Legal Theories. Cambridge: Cambridge University Press, 1997.

27 'ARAFA, Mohamed. Whither Egypt? Against Religious Fascism and Legal Authoritarianism: Pure Revolution, Popular Coup, or a Military Coup d'état? Indiana International and Comparative Law Review, Indianopolis, vol. 24, n. 4, p. 859-897, 2014. p. 882.

28 HALLAQ, Wael. A History of Islamic Legal Theories. Cambridge: Cambridge University Press, 1997.

29 ABOU EL-FADEL, Khaled. Conceptualizing Shari'ah in the Modern State. Villanova Law Review, Villanova, vol. 56, n. 5 , p. $803-818,2012$. p. 810-811. 
position of superiority over the statutory rules. 30 Thus, the Sharie' $a$ eteronomy is not in contradiction with the social contract's nature of the constitution, as a derivative-society process. ${ }^{31}$ The Court's interpretation of the Islamic rules launched a moderate, non-fundamentalist interpretation, so modernizing from traditional fiqh. 32 Moreover, the SCC's commitment in the Sharie'a rules analysis has contributed to the liberal formation's energies by entrusting the conservation of Egyptian Islamic law to a principally secular institution-the SCC-while admitting commitment to the Sharie'a constitutional principality. Besides, though its decisions often take the attitudes of significant religious leaders (mufti/al-Azhar Grand Shiekh) into account, the SCC generally likes a fairly moderate interpretation of the rules into practical strategies for public life, as it yet works as a bumper between this coalition and the strength of radicalism.33 $\mathrm{A}$ distinction between the judicial task (applying the law) and the political role (lawmaking) is imperative in that respect, as judges do not apply the Constitution only, they have to deduce what it means and entails prior to applying it, and even they have discretion to interpret the materials irrespective of how obvious constitutional makers pursue their language to be. ${ }^{34}$

As a matter of fact, once introduced in the constitutional architecture, even the Sharie' $a$ clause desires an interpreter, and it is possible to consider the SCC as a "final" constitutional interpreter (Methodology + Coordination with other "interpretative forces"). 35 Regarding the plural Sharie' $a$ and the multiplicity of interpreters, not only judges may interpret the constitution. Rather, a major democratization flows from the intrinsic openness of the constitutional interpretation «who lives the norms may interpret the norms» (Brown \& Lombardi 2006). ${ }^{36}$ Citizens, groups, and judicial bodies are in

\footnotetext{
30 SHERIF, Adel. Constitutional Law. In: MAUGIRON Nathalie; DUPRET Baudouin (Eds.). Egypt and its Laws. London : Kluwer law international, 2002. p. 25.

31 SULTANY, Nimer. The State of Progressive Constitutional Theory: The Paradox of Constitutional Democracy and the Project of Political Justification. Harvard Civil Rights-Civil Liberties Law Review, Cambridge, vol. 47, n. 2, p. 371-455, mar./june 2012. p. 415-416.

32 ELMORR Awad et al. The Supreme Constitutional Court and Its Role in the Egyptian Judicial System. In: BOYLE, Kevin; SHERIF, Adel (Eds.). Human Rights and Democracy - The Role of the Supreme Constitutional Court of Egypt. Hague: Kluwer Law International, 1996.
}

33 For example, Decision 37, Judicial Year 9 (May 19, 1990) and Decision 25, Judicial Year 16 (July 3, 1995). 34 SULTANY, Nimer. Religion and Constitutionalism: Lessons from American and Islamic Constitutionalism. Emory International Law Review, Atlanta, vol. 28, n. 1, 345-424, 2014. p. 374-385; KOPPELMAN, Andrew. Phony Originalism and the Establishment Clause. Northwestern University Law Review, Evanston, vol. 103, n. 2, p. 1-23, 2003.

35 'ARAFA, Mohamed. Whither Egypt? Against Religious Fascism and Legal Authoritarianism: Pure Revolution, Popular Coup, or a Military Coup d'état? Indiana International and Comparative Law Review, Indianopolis, vol. 24, n. 4, p. 859-897, 2014. p. 892-896.

36 BROWN, Nathan; LOMBARDI, Clark. The Supreme Constitutional Court of Egypt on Islamic Law, Veiling and Civil Rights: An Annotated Translation of Supreme Constitutional Court of Egypt Case No. 8 of Judicial Year 17 (May 18, 1996). American University International Law Review, Washington, vol. 21, n. 3, p. 437-460, june 2006. 
a strict sense "informative forces" of the constitution; parties and experts are dynamic as pre-interpreters of the law, proposing some sort of interpretations, and the SCC represents a particular mediator between the State and the community, and its role may be assumed as a form of democratization of the clauses' interpretation. Harvard Law School Professor Noah Feldman argues that "secularism of the Western variety is not a necessary condition of democracy" in order to justify the lack of separation between religion and State under an "Islamic democracy".37 Likewise, Lama Abu-Odeh has stated:

Islamic law should be approached as one, but only one, of the constitutive elements of law that has not only been decentered by the transplant but also transformed. Not only have its rules been reformed, but also its modes of reasoning, and its jurist class. Its treatises have been turned into codes, and its qadis turned into modern judges. Moreover, its internal conceptual organization, has been transformed by being reduced to a rule structure positivized in a code and dependent on State enforcement. Consequently, its normative hold over people has changed. 38

Judicial authorization through a Sharie' $a$ clause is an diverting secular approach; that the obsession with this clause is part of extreme constitutional interest; and that validation of religious issues flings the ball from the political field to the legal scene. So, constitutionalizing the Sharie' $a$ hampers the awareness of the main political duty. The acknowledgement of the puzzling presence of Islamic constitutionalism (Islam and democratic norms) should lead to the constant openness of the compromise between the ethical and political arenas (pluralism). ${ }^{39}$ Thus, when anticipating essential religion and state demands, constitutional courts in religious democracies (members' philosophical favorites + their own perceptive strategies) are powerfully motivated to rule within the community's interests and prospects of liberal groups and authority holders. 40 Supreme Court justices may be observed as tactical artists to the level that they pursue to preserve or enrich the court's influential position vis-à-vis other foremost domestic decision, law, and policymaking apparatuses. Judges may agree upon playing it safe either by abstaining to decide or issuing equivocal/conventional rulings when the established motivation structure or political circumstances within which they function are not beneficial to judicial modernization (hyperactivism). This judicial shifting emerges a key conundrum: how to guarantee that the courts will release decisions that echo

37 FELDMAN, Noah. After Jihad: America and the Struggle for Islamic Democracy. New York: Farrar, Straus and Giroux, 2003. p. 12.

38 ABU-ODEH, Lama. The Politics of (Mis)recognition: Islamic Law Pedagogy in American Academia. American Journal of Comparative Law, Washington, vol. 52, p. 789-824, jan. 2004.

39 MOUFFE, Chantal. The Democratic Paradox. London: Verso, 2000. p. 13-14; 102-105.

40 MOUSTAFA, Tamir. Conflict and Cooperation between the State and Religious Institutions in Contemporary Egypt. International Journal of Middle East Studies, Cambridge, vol. 32, n. 1, p. 3-22, jan. 2000. p. 11-16. 
the authority's ideological preferences. ${ }^{41}$ In constitutional systems, particularly those functioning in civil law practice, the constitution expressly mentions public rights/freedoms but leaves the issue of their meaning and regulation to legislation and this is a latent dodge, as a right can be robbed of much of its significance. In this case, the Court recited that "it is improper that any law can destabilize a freedom under the justification of regulating its practice, as once Muslims have acknowledged-with conclusiveness-a Sharie' $a$ universal principle (fixed rule in an undoubtedly authentic text with a definite meaning), they must follow this principle or rule "as is," and may not try to elucidate it away or reason out an alternative legal norm." 42

Still, there is some evidence that the "religious clause" or "repugnancy clause" doctrine is becoming influential within the Arab World. There are academic discussions on the topic in books and journals throughout the Middle Eastern and North African ("MENA") region. And the doctrine has migrated to Jordan and most recently to Tunisia. It remains to be seen whether these countries will also adopt other elements of the Egyptian SCC's ambitious model. More broadly, it remains to be seen whether the Egyptian structural approach will become a typical way of enforcing a moderate interpretation of Islamic [Sharie'a] law both inside and outside Egypt (MENA area, may be Western societies [Europe and USA]) as a key to the historic under-enforcement of this paradox through much of the region and as a way to reduce religious extremism.

\section{REFERENCES}

'ARAFA, Mohamed. President Mursi's Egypt Arab Spring: Does Egypt will Continue to be a Civil State or under the Umbrella of Islamic (Sharie'a) Law and Islamism? US-China Law Review, New York, vol. 9, n. 6, p. 1-18, dec. 2010.

'ARAFA, Mohamed. Whither Egypt? Against Religious Fascism and Legal Authoritarianism: Pure Revolution, Popular Coup, or a Military Coup d'état? Indiana International and Comparative Law Review, Indianopolis, vol. 24, n. 4, p. 859-897, 2014.

ABOU EL-FADEL, Khaled. Conceptualizing Shari'ah in the Modern State. Villanova Law Review, Villanova, vol. 56, n. 5, p. 803-818, 2012.

ABU-ODEH, Lama. The Politics of (Mis)recognition: Islamic Law Pedagogy in American Academia. American Journal of Comparative Law, Washington, vol. 52, p. 789-824, jan. 2004.

BROWN, Nathan; LOMBARDI, Clark. The Supreme Constitutional Court of Egypt on Islamic Law, Veiling and Civil Rights: An Annotated Translation of Supreme Constitutional Court of Egypt Case

41 ROY, Olivier. The Failure of Political Islam. Cambridge: Harvard University Press, 1994. p. 82-215.

42 BOYLE, Kevin; SHERIF, Adel (Eds.). Human Rights and Democracy - The Role of the Supreme Constitutional Court of Egypt. Hague: Kluwer Law International, 1996. p. 43-53. 
No. 8 of Judicial Year 17 (May 18, 1996). American University International Law Review, Washington, vol. 21, n. 3, p. 437-460, june 2006.

BROWN, Nathan. Islamic Constitutionalism in Theory and Practice. In: COTRAN, Eugene; SHERIF, Adel. (Eds.). Democracy, the Rule of Law and Islam. Hague: Kluwer Law International, 1999.

BROWN, Nathan; LOMBARDI, Clark. Do Constitutions Requiring Adherence to Shari'a Threaten Human Rights? How Egypt's Constitutional Court Reconciles Islamic Law with the Liberal Rule of Law. American University International Law Review, Washington, vol. 21, n. 3, p. 179-435, june 2006. BROWN, Nathan. The Rule of Law in the Ancient World: Courts in Egypt and the Gulf. Cambridge: Cambridge University Press, 1997.

ELMORR Awad et al. The Supreme Constitutional Court and Its Role in the Egyptian Judicial System. In: BOYLE, Kevin; SHERIF, Adel (Eds.). Human Rights and Democracy - The Role of the Supreme Constitutional Court of Egypt. Hague: Kluwer Law International, 1996.

ELMORR, Awad. The Supreme Constitutional Court of Egypt and the Protection of Human and Political Rights. In: MALLAT, Chibli (Ed.). Islam and Public Law. [s.l.]: Springer Netherlands, 1992.

FELDMAN, Noah. After Jihad: America and the Struggle for Islamic Democracy. New York: Farrar, Straus and Giroux, 2003.

HALLAQ, Wael. A History of Islamic Legal Theories. Cambridge: Cambridge University Press, 1997.

KOPPELMAN, Andrew. Phony Originalism and the Establishment Clause. Northwestern University Law Review, Evanston, vol. 103, n. 2, p. 1-23, 2003.

LOMBARDI, Clark. Designing Islamic Constitutions: Past Trends and Options for a Democratic Future. International Journal of Constitutional Law, Washington, vol. 11, n. 3, p. 615-645, sept. 2013.

LOMBARDI, Clark. Note, Islamic Law as a Source of Constitutional Law in Egypt: The Constitutionalization of the Shari'a in a Modern Arab State. Columbia Journal of Transnational Law, New York, vol. 37, 1998.

LOMBARDI, Clark. State Law as Islamic Law in Modern Egypt. Leida: Brill Academic Publishers, 2006.

MOUFFE, Chantal. The Democratic Paradox. London: Verso, 2000.

MOUSTAFA, Tamir. Conflict and Cooperation between the State and Religious Institutions in Contemporary Egypt. International Journal of Middle East Studies, Cambridge, vol. 32, n. 1, p. 3-22, jan. 2000.

SHERIF, Adel. The Rule of Law in Egypt from a Judicial Perspective: A Digest of the Landmark Decisions of the Supreme Constitutional Court. In: CTRAN Eugene; YAMANI, Mai (Eds.). The Rule of 
Law in the Middle East and the Islamic World: Human Rights and the Judicial Process. London: I.B.Tauris, 2000.

ROY, Olivier. The Failure of Political Islam. Cambridge: Harvard University Press, 1994.

RUGH, Andrea. Reveal and Conceal: Dress in Contemporary Egypt. Syracuse: Syracuse University Publications in Continuing Education, 1987.

SHERIF, Adel. Constitutional Law. In: MAUGIRON Nathalie; DUPRET Baudouin (Eds.). Egypt and its Laws. London : Kluwer law international, 2002.

SULTANY, Nimer. Religion and Constitutionalism: Lessons from American and Islamic Constitutionalism. Emory International Law Review, Atlanta, vol. 28, n. 1, 345-424, 2014.

SULTANY, Nimer. The State of Progressive Constitutional Theory: The Paradox of Constitutional Democracy and the Project of Political Justification. Harvard Civil Rights-Civil Liberties Law Review, Cambridge, vol. 47, n. 2, p. 371-455, mar./june 2012.

VOGEL, Frank. Conformity with Islamic Shari'a and Constitutionality under Article 2: Some Issues of Theory, Practice, and Comparison. In: COTRAN, Eugene; SHERIF, Adel. (Eds.). Democracy, the Rule of Law and Islam. Hague: Kluwer Law International, 1999.

WEHR, Hans. A Dictionary of Modern Written Arabic [s.I.]: Milton Cowan ed., 1974. 